Web Jurnal:

http://ejournal.kemenperin.go.id/jli

\title{
Pengaruh suhu dan waktu pengeringan terhadap rendemen kemiri utuh yang dipecah secara mekanis
}

\section{Effect of drying temperature and drying time on the yield of mechanically peeled candlenut}

Yunia Angraeni, Citra Setiawati*, Muhammad Fajri Nurmawan, dan Nur Aini Haryati

Balai Riset dan Standardisasi Industri Padang

Jl. Raya LIK No. 23 Ulu Gadut Padang 25164, Indonesia

* e-mail: citra.yep@gmail.com

\begin{tabular}{l}
\hline INFO ARTIKEL \\
\hline Sejarah artikel: \\
Diterima: \\
18 November 2019 \\
Direvisi: \\
17 Desember 2019 \\
Diterbitkan: \\
30 Desember 2019 \\
\hline
\end{tabular}

\section{Kata kunci:}

kemiri;

suhu pengeringan;

waktu pengeringan

\begin{abstract}
ABSTRAK
Kemiri (Aleurites mollucana Wild) merupakan salah satu hasil hutan bukan kayu yang bijinya dimanfaatkan untuk keperluan pangan serta bahan sediaan farmasi dan kosmetika. Pemecahan biji kemiri dari cangkangnya secara tradisional menyebabkan banyak inti kemiri rusak sedangkan pemecahan dengan mesin pemecah kemiri dengan sistem ripple mill menghasilkan rendemen kemiri utuh di bawah $40 \%$. Penelitian ini dilakukan untuk mengetahui pengaruh suhu dan waktu pengeringan terhadap rendemen dan kualitas kemiri utuh yang dipecah secara mekanis menggunakan mesin pemecah kemiri sistem ripple mill dengan variasi suhu pengeringan 50,60 dan $70{ }^{\circ} \mathrm{C}$ dan variasi waktu pengeringan selama 1, 2, 3, 4 dan 5 hari. Hasil penelitian menunjukkan bahwa pemecahan kemiri utuh secara optimal diperoleh pada perlakuan suhu pengeringan $70^{\circ} \mathrm{C}$ selama 3 hari dengan rendemen kemiri utuh sebanyak $64,71 \%$, inti kemiri pecah dua $20,59 \%$, inti kemiri lengket sebanyak $8,82 \%$ dan inti kemiri hancur 5,88\%. Hasil uji mutu inti kemiri menunjukkan bahwa pada perlakuan tersebut diperoleh inti kemiri dengan kandungan air sebesar 1,4846 \% (b/b).
\end{abstract}

Keywords:

candlenut;

drying temperature;

drying time

\begin{abstract}
Candlenut (Aleurites mollucana Wild) is one of the non-timber forest products whose seeds are used for food and pharmaceutical and cosmetic preparations. The breakdown of candlenut seeds from their shells has traditionally caused much damage to the candlenut kernel while breaking it using the machine with ripple mill system produces a yield of whole candlenuts below 40\%. This research was conducted to determine the effect of drying temperature and drying time on the yield and quality of whole candlenut that is broken down mechanically using a ripple mill system with variations in drying temperature of 50, 60 and $70^{\circ} \mathrm{C}$ and variations in drying time for 1, 2, 3, 4 and 5 days. The results showed that the optimal cracking of the whole candlenut was obtained at a treatment temperature of $70{ }^{\circ} \mathrm{C}$ for 3 days with percentage of unbroken candlenut kernel is $64.71 \%$, broken candlenut kernel is $20.59 \%$, sticky candlenut kernel is $8.82 \%$ and destroyrd candlenut kernel is $5.88 \%$. Candlenut kernel quality test results indicate that in the treatment obtained candlenut kernel with water content of $1,4846 \% \mathrm{w} / \mathrm{w}$.
\end{abstract}

\section{Pendahuluan}

Aleurites moluccana (L.) Willd., atau lebih dikenal dengan nama kemiri, merupakan salah satu pohon serbaguna yang sudah dibudidayakan secara luas di dunia. Jenis ini berasal dari wilayah Indo-Malaysia dan telah diperkenalkan ke Kepulauan Pasifik sejak jaman dahulu. Di Indonesia, kemiri telah lama ditanam, baik untuk tujuan komersial maupun substituen untuk menunjang kehidupan masyarakat sehari-hari, terutama bagi masyarakat Indonesia bagian timur (Krisnawati et al., 2011).

Hampir semua bagian dari pohon kemiri seperti daun, buah, kulit, kayu, akar, getah dan bunganya dapat dimanfaatkan, baik untuk obat-obatan tradisional, bahan bangunan, bahan pewarna, bahan makanan, maupun 
berbagai kegunaan lain (González-Stuart and Rivera, 2019; Siallagan et al., 2012). Batang pohon kemiri dapat digunakan untuk kayu bakar (Jasman et al., 2018). Kulit pohon kemiri dimanfaatkan sebagai obat diare (Mac Donald et al., 2016). Bagian tempurung kemiri digunakan sebagai bahan baku karbon aktif dalam adsorpsi logam Fe (Prabarini and Okayadnya, 2013). Kulit kemiri dapat diekstrak untuk menghasilkan pektin yang dapat digunakan sebagai bahan perekat/pengental (gelling agent). Biji kemiri digunakan untuk obat sembelit dengan cara ditumbuk dan dibakar dengan menggunakan arang, kemudian dioleskan ke sekitar pusar (perut) (Pardede et al., 2013). Biji kemiri yang kaya akan kandungan lemak dapat digunakan sebagai bahan masakan, farmasi dan bahan penerangan dengan cara dibakar langsung atau diolah menjadi lilin (Husain and Tuiyo, 2012). Bunga dan getah segar kemiri yang baru saja disadap digunakan untuk obat sariawan pada anak-anak. Selain itu, biji kemiri yang kering juga lazim digunakan sebagai bahan masakan di berbagai negara (Arlene et al., 2013).

Minyak yang diekstrak dari biji kemiri dapat menghasilkan metil dan etil ester melalui metode transesterifikasi (Cabral et al., 2016). Biji kemiri yang telah ditumbuk dapat digunakan sebagai bahan pembuatan sabun, sebagai perangsang pertumbuhan rambut dan sebagai bahan aditif dalam perawatan rambut (Husain and Tuiyo, 2012). Saat ini minyak kemiri dengan kualitas tinggi sudah menjadi produk komersial utama dan dijual secara luas di industri. Lebih lanjut lagi, sisa biji yang sudah diekstrak minyaknya dapat dimanfaatkan sebagai pupuk dan bahan baku industri lainnya (Herman et al., 2013).

Meningkatnya permintaan kemiri dari negara lain membuat petani di Indonesia semakin giat menjadikan kemiri sebagai tanaman utama (Tridge, 2019). Biji kemiri memiliki manfaat dan nilai jual yang sangat tinggi apabila sudah melalui proses pengupasan yang baik dan benar (Iskandar et al., 2016; Manap et al., 2009). Karakteristik secara fisik dari kulit biji kemiri adalah sangat keras dan mempunyai ketebalan yang berbeda antara satu sama lain, maka untuk memecahkan biji kemiri memerlukan teknologi dan perlakuanperlakuan yang sangat khusus pada biji kemiri supaya mendapatkan hasil pemecahan kulit biji kemiri yang bagus dan menghasilkan daging kemiri yang utuh (Argo et al., 2018).

Beberapa kegiatan perekayasaan sebelumnya telah dilakukan untuk memperoleh kemiri dengan kualitas tinggi dengan merekayasa alat pemecah kemiri dengan mekanisme pemecahan tertentu seperti sistem bentur (Sumardi, 2013), sistem ripple mill (Siallagan et al., 2012), sistem roll (Jasman et al., 2018), dan sistem screw press (Chynintya and Vita, 2018). Salah satu sistem pemecahan kemiri yang efektif yaitu menambahkan mesin grading untuk mensortasi besarnya kemiri pada mesin pemecah kemiri. Melalui kombinasi kedua tahapan tersebut maka pemecahan kulit kemiri gelondongan dapat memberikan hasil/produktivitas yang lebih tinggi.

Kinerja alat dan kualitas mutu hasil pengupasan cangkang kemiri dengan alat mekanis dipengaruhi oleh beberapa faktor yaitu suhu pengeringan, waktu pengeringan, suhu pembekuan, lama pembekuan, suhu perendaman, lama perendaman, jenis kemiri, diameter landasan banting dan kecepatan putaran mesin (rpm) (Lumbantoruan et al., 2014; Siallagan et al., 2012).

Penelitian ini bertujuan untuk mengetahui pengaruh faktor suhu dan waktu pengeringan terhadap jumlah kemiri utuh yang diperoleh dari proses pemecahan menggunakan mesin pemecah kemiri. Biji kemiri yang akan diproses sebelumnya diberikan perlakuan dengan pengeringan dalam oven pada suhu dan waktu pengeringan yang bervariasi. Hal ini dilakukan untuk menentukan kondisi pengeringan yang optimal untuk memperoleh inti kemiri utuh pada proses pemecahan cangkang kemiri. Penentuan pengaruh suhu dan waktu pengeringan terhadap alat pemecah cangkang kemiri ini diharapkan dapat meningkatkan efektivitas dan efisiensi dari alat tersebut sehingga dapat meningkatkan produktivitas dari industri kemiri serta meningkatkan daya saing dan harga jual produk kemiri.

\section{Metode}

Bahan kemiri diperoleh dari petani kemiri di Kecamatan Bayang Utara Kabupaten Pesisir Selatan, Sumatera Barat. Peralatan yang digunakan adalah oven, freezer, botol timbang, desikator, neraca analitik, baskom, mesin sortasi dan mesin pemecah cangkang kemiri sistem ripple mill dengan kempa ulir berkapasitas $60 \mathrm{~kg} / \mathrm{jam}$.

\subsection{Sortasi kemiri gelondongan}

Kemiri gelondongan yang diperoleh dengan berbagai ukuran perlu disortir untuk memudahkan penyetelan ukuran roll pada mesin pemecah cangkang kemiri dan proses pemecahan cangkang menjadi lebih efektif. Kemiri gelondongan dimasukan ke dalam mesin sortasi melalui corong. Mesin sortasi yang digerakkan oleh penggerak elektro motor akan memisahkan biji kemiri melewati empat tingkat saringan kawat/wiremesh yang memiliki ukuran tulangan masing-masing $16 \mathrm{~mm}, 20$ $\mathrm{mm}, 25 \mathrm{~mm}$, dan $30 \mathrm{~mm}$.

\subsection{Pengeringan kemiri}

Proses pengeringan kemiri dapat dilakukan dengan penjemuran secara alami maupun pengeringan menggunakan oven. Penjemuran di bawah sinar matahari dilakukan dengan menghamparkan kemiri di atas terpal selama 3-6 hari. Pengeringan dengan oven dapat dilakukan pada suhu $50-70{ }^{\circ} \mathrm{C}$ untuk mendapatkan hasil terbaik (Sinaga, 2010). Pada penelitian ini pengeringan kemiri dilakukan dengan memanaskan kemiri dalam oven dengan variasi suhu $50^{\circ} \mathrm{C}, 60{ }^{\circ} \mathrm{C}$ dan $70{ }^{\circ} \mathrm{C}$ dan waktu pengeringan selama 1 hari, 2 hari, 3 hari, 4 hari dan 5 hari.

\subsection{Pendinginan kemiri}

Biji kemiri yang telah dikeringkan segera didinginkan dengan cara memasukkan kemiri yang telah dikeringkan ke dalam freezer pada suhu $0{ }^{\circ} \mathrm{C}$ selama 8 jam. 


\subsection{Pemecahan cangkang kemiri}

Pemecahan cangkang kemiri secara mekanis dilakukan menggunakan mesin pemecah kemiri dengan sistem riplle mill menggunakan kempa ulir yang dapat disesuaikan dengan ukuran kemiri.

Kemiri dimasukkan ke dalam alat pemecah kemiri melalui corong pemasukkan secara bertahap untuk menghindari penumpukan bahan baku pada saluran pemasukan. Buah kemiri yang masih dalam bentuk gelondongan masuk ke dalam screw press. Di dalam ruang roll pemecah cangkang, bahan kemiri akan dilontarkan dan akan tertumbuk oleh papan press. Selanjutnya buah kemiri yang tertumbuk akan keluar melalui corong keluar. Setelah proses pemecahan selesai, dilakukan pemisahan buah kemiri dari pecahan kulitnya secara manual.

Terhadap hasil pemecahan cangkang kemiri kemudian dilakukan pengamatan dan parameter yang diamati adalah persentase inti utuh (\%), persentase inti pecah dua (\%), persentase inti hancur (\%), dan persentase inti lengket (\%). Diagram alir proses pemecahan kemiri dapat dilihat pada Gambar 1.

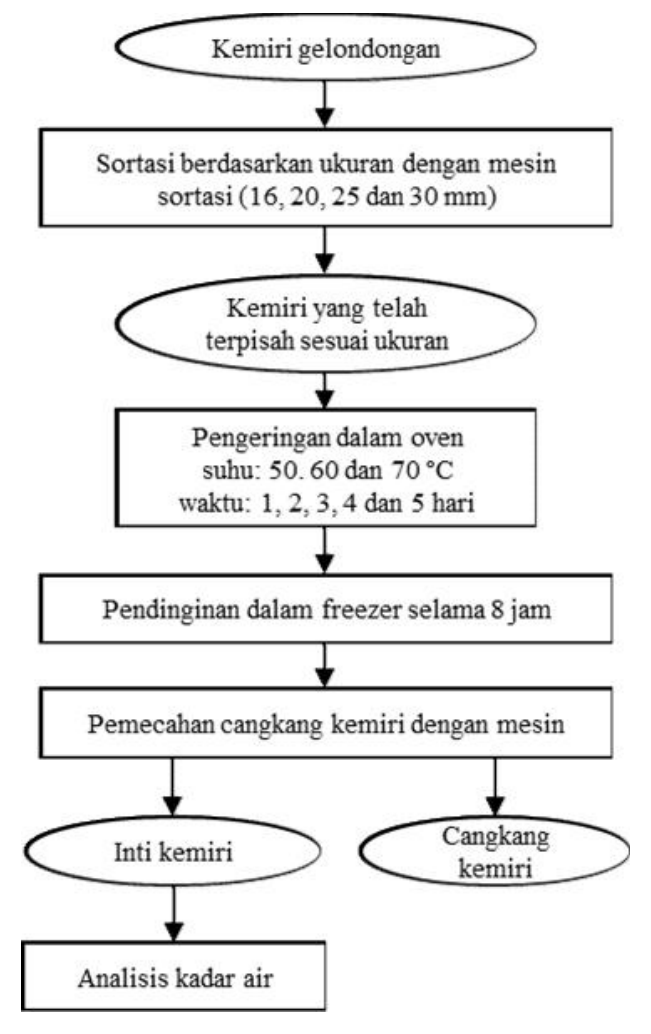

Gambar 1. Diagram alir proses pemecahan kemiri

\subsection{Uji kadar air}

Inti kemiri yang diperoleh dari proses pemecahan kemiri kemudian diuji kandungan airnya. Analisis kadar air dilakukan dengan metode gravimetri menggunakan oven sesuai SNI 01-2891-1992, Cara Uji Makanan dan
Minuman butir 5.2. Kadar air dihitung dengan persamaan (1).

$$
\text { Kadar air }=\frac{\mathrm{w}}{\mathrm{w}_{1}} \times 100 \%
$$

Keterangan:

$$
\begin{aligned}
& \mathrm{w}=\text { bobot cuplikan sebelum dikeringkan }(\mathrm{g}) \\
& \mathrm{w}_{1}=\text { bobot yang hilang setelah dikeringkan }(\mathrm{g})
\end{aligned}
$$

\section{Hasil dan pembahasan}

Pengeringan kemiri dengan oven pada suhu $50{ }^{\circ} \mathrm{C}$, $60^{\circ} \mathrm{C}$ dan $70{ }^{\circ} \mathrm{C}$ selama $1-5$ hari dalam oven bertujuan untuk merapuhkan kulit biji kemiri dan memisahkan kulit biji kemiri dengan kulit ari daging kemiri sehingga mudah pada saat proses pemecahan dengan mesin. Hasil pemecahan kemiri yang diperoleh pada masing-masing variasi perlakuan ditampilkan pada Tabel 1. Grafik persentase hasil inti kemiri pada masing-masing perlakuan dapat dilihat pada Gambar 2.

Tabel 1.

\begin{tabular}{|c|c|c|c|c|c|}
\hline \multicolumn{2}{|c|}{ Perlakuan } & \multicolumn{4}{|c|}{ Hasil inti kemiri (\%) } \\
\hline $\begin{array}{l}\text { Suhu } \\
\left({ }^{\circ} \mathrm{C}\right)\end{array}$ & $\begin{array}{l}\text { Waktu } \\
\text { (hari) }\end{array}$ & Utuh & $\begin{array}{l}\text { Pecah } \\
\text { dua }\end{array}$ & Lengket & Hancur \\
\hline \multirow{5}{*}{50} & 1 & 36,23 & 24,64 & 30,43 & 8,70 \\
\hline & 2 & 51,28 & 15,38 & 30,77 & 2,57 \\
\hline & 3 & 54,62 & 17,69 & 26,16 & 1,53 \\
\hline & 4 & 55,77 & 17,85 & 25,00 & 1,38 \\
\hline & 5 & 55,56 & 12,70 & 30,16 & 1,58 \\
\hline \multirow{5}{*}{60} & 1 & 33,33 & 35,00 & 28,33 & 3,34 \\
\hline & 2 & 46,67 & 23,33 & 25,00 & 5,00 \\
\hline & 3 & 61,70 & 23,40 & 12,77 & 2,13 \\
\hline & 4 & 62,00 & 22,00 & 14,00 & 2,00 \\
\hline & 5 & 61,54 & 23,08 & 12,31 & 3,07 \\
\hline \multirow{5}{*}{70} & 1 & 51,02 & 20,41 & 24,49 & 4,08 \\
\hline & 2 & 52,08 & 14,58 & 29,17 & 4,17 \\
\hline & 3 & 64,71 & 20,59 & 8,82 & 5,88 \\
\hline & 4 & 52,38 & 28,57 & 14,29 & 4,76 \\
\hline & 5 & 51,16 & 23,26 & 18,60 & 6,98 \\
\hline
\end{tabular}

Persentase hasil pemecahan kemiri dengan variasi suhu dan waktu pengeringan

Pengeringan dengan oven pada suhu $50^{\circ} \mathrm{C}$ menghasilkan persentase hasil inti kemiri utuh tertinggi pada waktu pengeringan selama 4 hari sebesar $55,77 \%$ sedangkan persentase terendah diperoleh pada waktu pengeringan selama 1 hari. Pada pengeringan dengan suhu $60{ }^{\circ} \mathrm{C}$ persentase hasil inti kemiri utuh tertinggi dicapai pada waktu pengeringan selama 4 hari sebesar $62,00 \%$ sedangkan persentase terendah dicapai pada waktu pengeringan selama 1 hari sebesar $33,33 \%$. Pada pengeringan dengan suhu $70{ }^{\circ} \mathrm{C}$, persentase hasil inti kemiri utuh tertinggi dicapai pada waktu pengeringan selama 3 hari sebesar $64,71 \%$ sedangkan persentase terendah diperoleh pada waktu pengeringan selama 1 hari. 


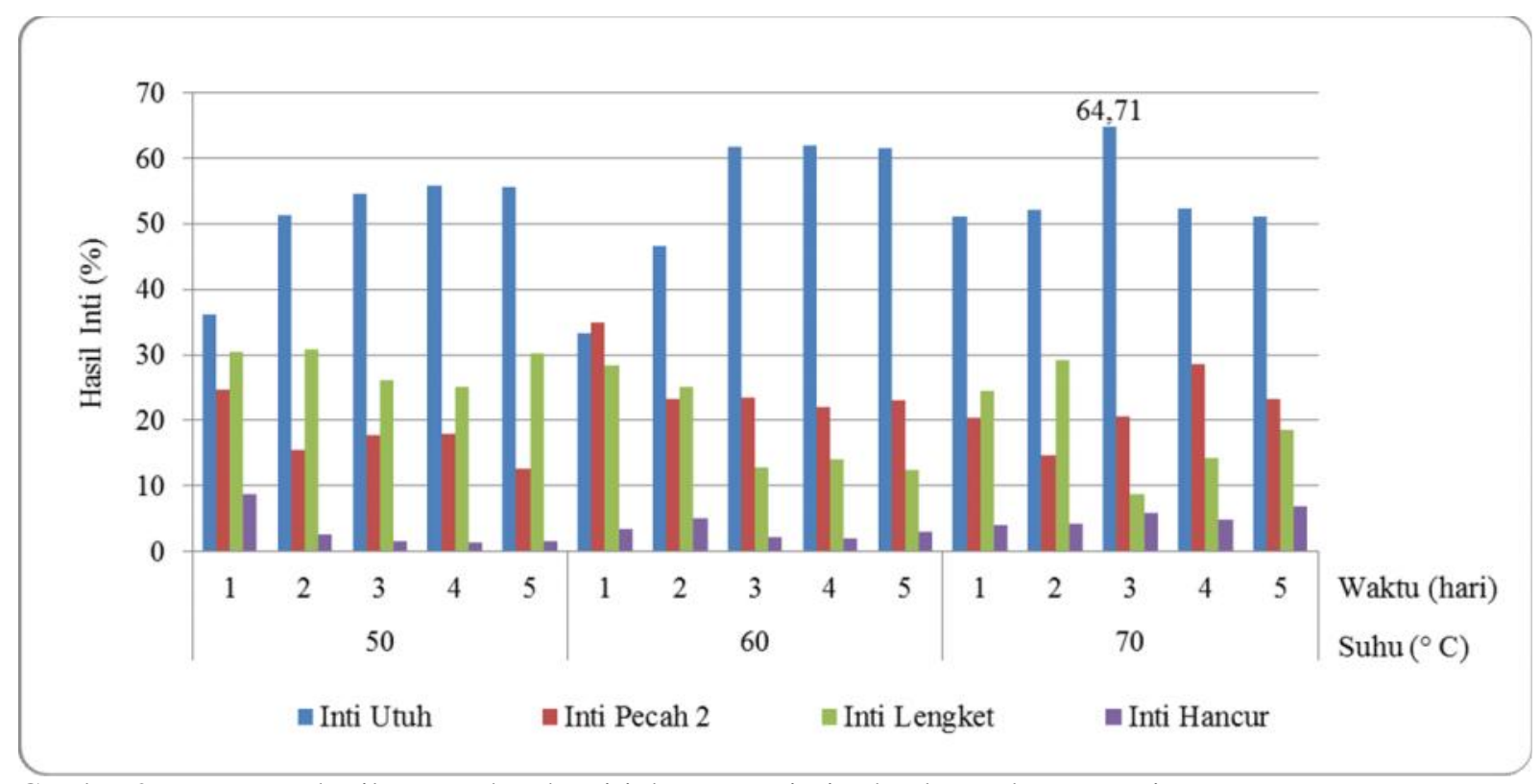

Gambar 2. Persentase hasil pemecahan kemiri dengan variasi suhu dan waktu pengeringan

Tabel 2.

Hasil analisis variasi (ANOVA) pengaruh suhu dan waktu pengeringan pada persentase inti kemiri utuh

\begin{tabular}{lllllll}
\hline Source of Variation & SS & $d f$ & $M S$ & $F$ & P-value & F crit \\
\hline Suhu Pengeringan & 33,07684 & 2 & 16,53842 & 0,414009 & 0,674384 & 4,45897 \\
Waktu Pengeringan & 749,0159 & 4 & 187,254 & 4,687557 & 0,030427 & $3,837853 *$ \\
Error & 319,5762 & 8 & 39,94703 & & & \\
Total & 1101,669 & 14 & & & & \\
\hline
\end{tabular}

Dari analisis variansi pada Tabel 2, diketahui bahwa persentase inti kemiri utuh tidak dipengaruhi oleh variasi suhu pengeringan $(F<F$ crit $)$ sedangkan waktu pengeringan berpengaruh secara signifikan pada persentase inti kemiri utuh $(F>F$ crit $)$. Hal ini sejalan dengan Winarni et al. (2005) bahwa variasi waktu pengeringan dalam oven memberikan pengaruh yang berbeda nyata pada hasil inti kemiri utuh.

Pada pengeringan dengan suhu $50{ }^{\circ} \mathrm{C}$, inti kemiri yang pecah dua mencapai persentase tertinggi sebesar $24,64 \%$ dengan waktu pengeringan satu hari dan persentase terendah diperoleh pada waktu pengeringan selama 5 hari sebesar $12,70 \%$. Pada pengeringan dengan suhu $60{ }^{\circ} \mathrm{C}$, inti kemiri yang pecah dua mencapai persentase tertinggi sebesar $35,00 \%$ dengan waktu pengeringan satu hari dan persentase terendah diperoleh pada waktu pengeringan selama 4 hari sebesar $22,00 \%$. Pada pengeringan dengan suhu $70{ }^{\circ} \mathrm{C}$, inti kemiri yang pecah dua mencapai persentase tertinggi sebesar $28,57 \%$ dengan waktu pengeringan 4 hari sedangkan persentase terendah diperoleh pada waktu pengeringan selama 2 hari sebesar $14,58 \%$.

Presentase hasil inti kemiri lengket pada pengeringan dengan suhu $50{ }^{\circ} \mathrm{C}$ tidak jauh berbeda untuk setiap variasi waktu pengeringan yaitu antara $25,00 \%$ pada pengeringan selama 4 hari hingga $30,77 \%$ untuk pengeringan selama 2 hari. Pada pengeringan dengan suhu $60{ }^{\circ} \mathrm{C}$, inti kemiri lengket mencapai persentase tertinggi sebesar $28,33 \%$ dengan waktu pengeringan 1 hari dan persentase terendah diperoleh pada waktu pengeringan selama 5 hari sebesar 12,31\%. Pada pengeringan dengan suhu $70{ }^{\circ} \mathrm{C}$, inti kemiri lengket mencapai persentase tertinggi sebesar $29,17 \%$ dengan waktu pengeringan 2 hari sedangkan persentase terendah diperoleh pada waktu pengeringan selama 3 hari sebesar $8,82 \%$.

Adapun persentase hasil inti kemiri hancur pada pengeringan dengan suhu $50{ }^{\circ} \mathrm{C}$ paling tinggi diperoleh pada pengeringan selama 1 hari sebesar $8,70 \%$ dan paling rendah diperoleh pada pengeringan selama 4 hari sebesar $1,38 \%$. Pada pengeringan dengan suhu $60{ }^{\circ} \mathrm{C}$, inti kemiri hancur mencapai persentase tertinggi sebesar $5,00 \%$ dengan waktu pengeringan 2 hari dan persentase terendah diperoleh pada waktu pengeringan selama 4 hari sebesar 2,00\%. Pada pengeringan dengan suhu $70^{\circ} \mathrm{C}$, inti kemiri hancur mencapai persentase tertinggi sebesar $6,98 \%$ dengan waktu pengeringan 5 hari sedangkan persentase terendah diperoleh pada waktu pengeringan selama 1 hari sebesar 4,08\%.

Selain suhu dan waktu pengeringan, keutuhan biji kemiri yang dipecah juga dipengaruhi oleh mutu kemiri, kadar air, keterampilan pengupasan dan perlakuan pendahuluan seperti suhu pembekuan dan waktu pembekuan (Argo et al., 2018; Siallagan et al., 2012). Faktor lain yang juga menentukan perolehan inti utuh adalah jenis kemiri, bentuk kemiri, sortasi ukuran kemiri dan kecepatan putar mesin.

Kemiri yang lengket pada cangkangnya disebabkan oleh proses pengeringan yang tidak sempurna sehingga kadar air pada biji kemiri masih tinggi dan menyebabkan daging kemiri sulit terlepas dari cangkang saat dipecah 
secara mekanis menggunakan mesin pemecah kemiri (Winarni et al., 2005).

Selain pengeringan dalam oven, perlakuan pendahuluan yang juga berperan pada keutuhan kemiri adalah pendinginan. Pendinginan kemiri dalam freezer akan menyebabkan terjadinya pemuaian pada bagian luar kulit kemiri. Pemuaian yang tidak merata di bagian kulit kemiri menyebabkan tidak terjadinya perenggangan antara sel-sel kulit dengan daging kemiri dan mempersulit proses cracking atau peretakan cangkang (Argo et al., 2018).

Berdasarkan data yang diperoleh, kondisi optimal untuk memperoleh inti kemiri utuh adalah pada suhu pengeringan $70{ }^{\circ} \mathrm{C}$ dan waktu pengeringan selama 3 hari. Pada perlakuan dengan kondisi tersebut, inti kemiri dengan cangkang telah memisah dengan baik dan menghasilkan kemiri utuh dengan sebesar $64,71 \%$.

Kemiri yang diperoleh dari proses pemecahan dengan mesin pemecah kemiri dianalisis kandungan airnya dan dibandingkan dengan kadar air kemiri yang dikeringkan secara konvensional dengan penjemuran di bawah sinar matahari. Berdasarkan hasil analisis mutu kemiri pada Tabel 3, diketahui bahwa kadar air memenuhi syarat mutu kemiri yang ditetapkan dalam SNI 01-1684-1998 yaitu kurang dari 5\% (b/b). Selain itu, jumlah air yang terkandung cenderung menurun seiring dengan peningkatan suhu dan waktu pengeringan.

Tabel 3.

Hasil uji kadar air biji kemiri

\begin{tabular}{llll}
\hline Perlakuan & $\begin{array}{l}\text { Suhu } \\
\left({ }^{\circ} \mathrm{C}\right)\end{array}$ & $\begin{array}{l}\text { Waktu } \\
(\text { hari })\end{array}$ & $\begin{array}{l}\text { Kadar air } \\
(\%(\mathrm{~b} / \mathrm{b}))\end{array}$ \\
\hline & & 1 & 3,1331 \\
& & 2 & 2,5303 \\
& 50 & 3 & 2,5839 \\
& & 4 & 2,3630 \\
& & 5 & 2,2857 \\
\cline { 2 - 4 } Pengeringan dengan & & 1 & 2,8243 \\
oven & 60 & 3 & 2,4359 \\
& & 4 & 2,0932 \\
& & 5 & 1,9439 \\
& & 1 & 2,8455 \\
\hline & & 2 & 1,8345 \\
& 70 & 3 & 1,4846 \\
& & 4 & 1,4908 \\
Penjemuran di bawah & - & 5 & 4,2504 \\
\hline
\end{tabular}

Perlakuan pengeringan kemiri menyebabkan cangkang kemiri lebih mudah untuk dipecahkan. Menurut Winarni et al. (2005) semakin lama proses pengeringan dengan oven maka tingkat jumlah inti kemiri utuh akan semakin tinggi. Hal ini dikarenakan selama pengeringan dalam oven kadar air dalam biji kemiri berkurang sehingga mempermudah daging kemiri terlepas dari selaput daging biji dan cangkangnya. Namun demikian pada perlakuan dengan suhu pengeringan $70{ }^{\circ} \mathrm{C}$, jumlah kemiri utuh menurun dengan meningkatnya waktu pengeringan pada 4 dan 5 hari. Hal ini dapat disebabkan karena proses pengeringan yang terlalu lama membuat inti kemiri menjadi rapuh dan turut hancur saat proses pemecahan menggunakan mesin dengan sistem ripple mill.

Dari hasil analisis kadar air pada kemiri dengan berbagai perlakuan, terlihat bahwa kadar air pada kemiri yang dikeringkan dengan oven lebih rendah dibandingkan dengan pengeringan secara konvensional dengan penjemuran di bawah sinar matahari. Menurut (Murad et al., 2015) pengeringan dengan oven lebih efisien karena tidak bergantung pada kondisi cuaca, kapasitas pengering disesuaikan dengan kebutuhan, tidak memerlukan tempat yang luas, serta kondisi pengeringan dapat dikontrol. Pengeringan dengan oven merupakan salah satu metode pengeringan yang dapat digunakan selain penjemuran dengan sinar matahari dan penyangraian. Pengeringan dengan menggunakan mesin pengering atau oven menghasilkan persentase kemiri utuh yang lebih besar dibandingkan dengan pengeringan secara konvensional dengan penjemuran di bawah sinar matahari (Argo et al., 2018).

Berdasarkan pengamatan terhadap kemiri yang telah dipecahkan, secara visual daging kemiri masih terlihat segar dan berwarna putih kekuningan dengan tekstur agak lunak. Gambar visual hasil proses pemecahan kemiri gelondongan pada kondisi pengeringan yang optimal dengan suhu $70{ }^{\circ} \mathrm{C}$ selama 3 hari dapat dilihat pada Gambar 3.

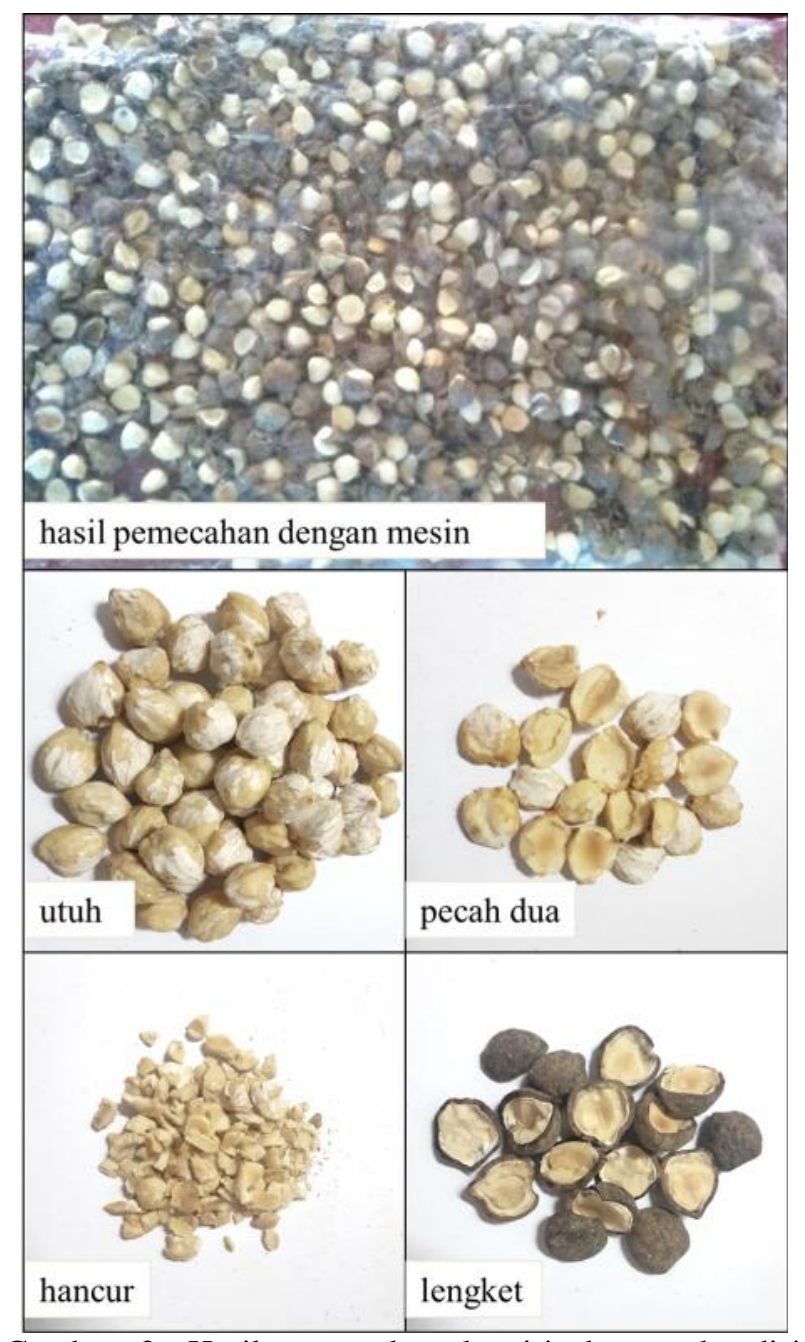

Gambar 3. Hasil pemecahan kemiri dengan kondisi pengeringan optimal pada suhu $70^{\circ} \mathrm{C}$ selama 3 hari 


\section{Kesimpulan}

Waktu pengeringan kemiri berpengaruh terhadap persentase inti kemiri utuh yang dihasilkan pada proses pemecahan secara mekanis menggunakan alat pemecah kemiri sedangkan suhu pengeringan dengan oven tidak berpengaruh nyata terhadap jumlah inti kemiri utuh. Kondisi pengeringan yang optimal diperoleh pada suhu pengeringan $70{ }^{\circ} \mathrm{C}$ dan waktu pengeringan selama 3 hari yang menghasilkan inti kemiri utuh sebesar $64,71 \%$, inti kemiri pecah dua sebesar $20,59 \%$, inti kemiri lengket sebesar 8,82\% dan inti kemiri hancur sebesar 5,88\%.

\section{Ucapan terima kasih}

Penulis mengucapkan terima kasih kepada Industri Kemiri Muaro Aie Kecamatan Bayang Utara Kabupaten Pesisir Selatan, Sumatera Barat beserta seluruh pihak yang terlibat dalam proses penulisan dan penyusunan artikel ini.

\section{Daftar pustaka}

Argo, B.D., H.S, S., Asdin, A., 2018. Pengaruh metode pengeringan terhadap karakteristik kupasan kemiri (Aleurites moluccana .L Willd). J. Keteknikan Pertan. Trop. dan Biosist. 4, 103-109.

Arlene, A., Suharto, I., Jessica, N.R., 2013. Pengaruh temperatur dan ukuran biji terhadap perolehan minyak kemiri pada ekstraksi biji kemiri dengan penekanan mekanis. Pros. Semin. Nas. Tek. Kim. "Kejuangan" Pengemb. Teknol. Kim. untuk Pengolah. Sumber Daya Alam Indones. 1-6.

Cabral, M.R.P., dos Santos, S.A.L., Stropa, J.M., da Silva, R.C. d. L., Cardoso, C.A.L., de Oliveira, L.C.S., Scharf, D.R., Simionatto, E.L., Santiago, E.F., Simionatto, E., 2016. Chemical composition and thermal properties of methyl and ethyl esters prepared from Aleurites moluccanus (L.) Willd (Euphorbiaceae) nut oil. Ind. Crops Prod. 85, 109116. https://doi.org/10.1016/j.indcrop.2016.02.058

Chynintya, G., Vita, P., 2018. Pengaruh temperatur, kecepatan putar ulir dan waktu pemanasan awal terhadap perolehan minyak kemiri dari biji kemiri dengan metode penekanan mekanis (screw press). Metana 12, 17-25. https://doi.org/10.14710/metana.v12i1.17511

González-Stuart, A.E., Rivera, J.O., 2019. Herbal weight loss supplements: from dubious efficacy to direct toxicity, Dietary Interventions in Liver Disease. Elsevier Inc., El Paso. https://doi.org/10.1016/b9780-12-814466-4.00014-8

Herman, M., Syakir, M., Pranowo, D., Saefudin, Sumanto, 2013. Kemiri sunan (Reutealis trisperma (Blanco) Airy Shaw) tanaman penghasil minyak nabati dan konversi lahan, 1st ed. IAARD Press, Jakarta.

Husain, I., Tuiyo, R., 2012. Pematahan dormansi benih kemiri (Aleurites moluccana, L. Willd) yang direndam dengan zat pengatur tumbuh organik basmingro dan pengaruhnya terhadap viabilitas benih. J. Agroteknotropika 1, 95-100.

Iskandar, R., Supardi, S., Harisudin, M., 2016. Candlenut efficiency analysis and marketing strategy (Aleurites moluccana) in Alor regency. Am. Sci. Res. J. Eng. Technol. Sci. 26, 101-121.

Jasman, J., Febriwanto, F., Putra, Z.A., 2018. Rancang bangun mesin pemecah buah kemiri dengan kapasitas $20 \mathrm{~kg} /$ jam (perancangan). J. Pendidik. Tek. Mesin 1, $1-13$.

Krisnawati, H., Maarit, K., Kanninen, M., 2011. Aleurites moluccana (L.) Willd. : ekologi, silvikultur dan produktivitas, I. ed. Center for International Forestry Research, Bogor, Indonesia.

Lumbantoruan, D., Rohanah, A., Rindang, A., 2014. Uji pengaruh suhu pemanasan biji kemiri dengan menggunakan oil press tipe ulir terhadap rendemen dan mutu minyak yang dihasilkan. J. Rekayasa Pangan dan Pertan. 2, 92-98.

Mac Donald, R., Camargo, S.S., Meyre-Silva, C., Quintão, N.L.M., Filho, V.C., Bresolin, T.M.B., Lucinda-Silva, R.M., 2016. Development of an oral suspension containing dry extract of Aleurites moluccanus with anti-inflammatory activity. Brazilian J. Pharmacogn. 26, 68-76. https://doi.org/10.1016/j.bjp.2015.06.011

Manap, N., Sidharta, M., Parera, A., 2009. Commodity chain assessment: case of candlenut in transboundary Timor and Indonesia. J. NTT Stud. 1, 147-158.

Murad, M., Sukmawaty, S., Sabani, R., Putra, G., 2015. Pengeringan biji kemiri pada alat pengering tipe batch model tungku berbasis bahan bakar cangkang kemiri. J. Ilm. Rekayasa Pertan. dan Biosist. 3, 122127.

Pardede, A., Ratnawati, D., Hp, A.M., 2013. Ekstraksi dan karakterisasi pektin dari kulit kemiri (Alleurites mollucana Willd). Media Sains 5, 1-6.

Prabarini, N., Okayadnya, D., 2013. Penyisihan logam besi $(\mathrm{Fe})$ pada air sumur dengan karbon aktif dari tempurung kemiri. J. Ilm. Tek. Lingkung. 5, 33-41.

Siallagan, A.Y., Daulay, S.B., Harahap, L.A., 2012. Pemecahan cangkang kemiri (Alleuirites mollucana) menggunakan sistem ripple mill dengan berbagai suhu perendaman. J. Rekayasa Pangan dan Pertan. I, 70-76.

Sinaga, F., 2010. Pengaruh suhu pengeringan dan suhu pembekuan terhadap mutu kemiri yang dipecah secara mekanis. Universitas Sumatera Utara.

Sumardi, S., 2013. Rancang bangun mesin pemecah biji kemiri dengan sistem bentur. Pros. Semin. Nas. Yusuf Benseh 1, 107-110.

Tridge, 2019. Candlenut suppliers, wholesale prices, and global market information - Tridge [WWW Document]. URL https://www.tridge.com/intelligences/candlenut (accessed 10.23.19).

Winarni, I., Suwardi, E., Marysofa, A., 2005. Pengaruh kombinasi perlakuan terhadap keutuhan biji kemiri. J. Penelit. Has. Hutan 23, 1-13. 